\title{
Development of Specific Fluorogenic Substrates for Human $\beta$ - $N$-Acetyl-D-hexosaminidase A for Cell-Based Assays
}

\author{
Kazuki Miura, Yuka Aoyama, Yurika Natsu, Ryosuke Koyama, Takako Hirano, \\ Toshiyuki Nishio, and Wataru Hakamata*
}

Department of Chemistry and Life Science, College of Bioresource Sciences, Nihon University; 1866 Kameino, Fujisawa, Kanagawa 252-0880, Japan.

Received January 23, 2020; accepted March 10, 2020

\begin{abstract}
Inhibitors of human $\beta$ - $N$-acetyl-D-hexosaminidase (hHEX) A and human $O$-GlcNAcase (hOGA) reportedly play roles in multiple diseases, suggesting their potential for pharmacological chaperone (PC) therapy of Sandhoff disease (SD) and Tay-Sachs disease (TSD), as lysosomal storage diseases, and Alzheimer's disease and progressive supranuclear palsy, respectively. In particular, hHEXA inhibitors as PCs have been shown to successfully enhance hHEXA levels, leading to the chronic form of SD and TSD. In the diagnosis of enzyme deficiencies in SD and TSD, artificial hHEXA substrates based on 4-methylumbelliferone as a fluorophore are available and generally used; however, they do not have sufficient performance to screen for potential inhibitors for a PC therapy from compound libraries. Further, there are currently few fluorogenic substrates for hHEXA suitable for such requirements and there are no substrates ideal for cell-based inhibitor screening. Here, we clarified the difference in enzyme active site structure between hHEXA and hOGA from their tertiary structures. To develop lysosome-localized hHEXA-specific fluorogenic substrates based on the difference in their active site structures, our developed quinone methide cleavage substrate design platform was applied for the molecular design of substrates. Thereafter, we synthesized via the shortest route and evaluated novel three-color fluorogenic substrates for hHEXA that exhibited excellent specificity and sensitivity in three human cell lines. The designed substrates represent the first-in-a class of new substrates that can be utilized to screen hHEXA inhibitors in adherent human cultured cells.
\end{abstract}

Key words $\beta$ - $N$-acetyl-D-hexosaminidase; fluorogenic substrate; inhibitor screening; lysosomal storage disease; pharmacological chaperone

\section{Introduction}

Human $\beta$ - $N$-acetyl-D-hexosaminidases (hHEXs), classified into the glycoside hydrolase $(\mathrm{GH})$ family 20, with three isozymes, namely hHEXA, hHEXB, and hHEXS, hydrolyze $\beta$-linked nonreducing-terminal 2-acetamido-2-deoxy-Dglucopyranoside (GlcNAc) or 2-acetamido-2-deoxy-Dgalactopyranoside (GalNAc) residues from many biomolecules in lysosomes. ${ }^{1)}$ These enzymes consist of an $\alpha$ subunit and a $\beta$ subunit, which contain their active site. Moreover, dimerization of the subunits is necessary for them to become fully functional. These lysosomal hHEXs are produced through the combination of the $\alpha$ and $\beta$ subunits to form any one of three active dimers, hHEXA ( $\alpha$ and $\beta$ subunits), hHEXB (two $\beta$ subunits), and hHEXS (two $\alpha$ subunits). hHEXA is the only isozyme that can hydrolyze GM2 ganglioside in humans, whereas hHEXB and hHEXS have no known physiological function and thus will not be considered further here. ${ }^{2)}$ Mutations in the $H E X B$ gene, which encodes the $\beta$ subunit, often result in Sandhoff disease (SD), whereas mutations in the HEXA gene, which encodes the $\alpha$ subunit, decrease the hydrolysis of GM2 gangliosides, which is the main cause of Tay-Sachs disease (TSD). ${ }^{3)}$ By contrast, hHEXs classified into the GH family 84 and called protein $O$-GlcNAcase (hOGA) have isoforms 1 and 3 , which remove a $\beta$-linked nonreducing-terminal GlcNAc residue but not GalNAc residue from $O$-glycosylated proteins in the cytoplasm and nucleus, respectively. ${ }^{4)}$ hOGAs are related to $O$-GlcNAc metabolism, and dysfunction in this essential physiological process leads to several human diseases such as cancer, type II diabetes, and Alzheimer's disease. ${ }^{5)}$

hHEXA inhibitors represent a pharmacological chaperone (PC) therapy that restores hHEXA protein and activity levels destabilized and reduced in disorders such as SD and TSD that arise from mutations. ${ }^{6}$ ) By contrast, inhibitors of hOGA have emerged as a promising therapeutic approach to treat tau pathology in neurodegenerative diseases such as Alzheimer's disease and progressive supranuclear palsy. These inhibitor studies have been advanced to first-in-human phase I clinical trials, ${ }^{7)}$ and although previous inhibitor studies used purified, recombinant, and commercially available hHEXA and hOGA from human or similar hexosaminidases from other species as substitutes for human enzymes for in vitro evaluation, they also evaluated the inhibitory activity of hHEXA and hOGA at the cellular level using indirect methods such as enzymelinked immunosorbent assay ${ }^{7,8}$ ) and fluorescence methods that require cell disruption. ${ }^{6,9)}$ To develop hHEXA and hOGA inhibitors into lead compounds toward drug development, it is necessary to evaluate their inhibitory activities against human-derived enzymes. Similarly, to provide an appropriate membrane permeability for inhibitors and to avoid cytotoxicity of inhibitors, suitable screening methods using human cultured cells are required.

Purified and recombinant hHEXA and hOGA are currently not commercially available, although recombinant hHEX classified into the GH family 89 and derived from the NAGLU gene is commercially available. Therefore, in this study, our goal was to develop specific fluorogenic substrates of hHEXA 
(A) hHEXA active site

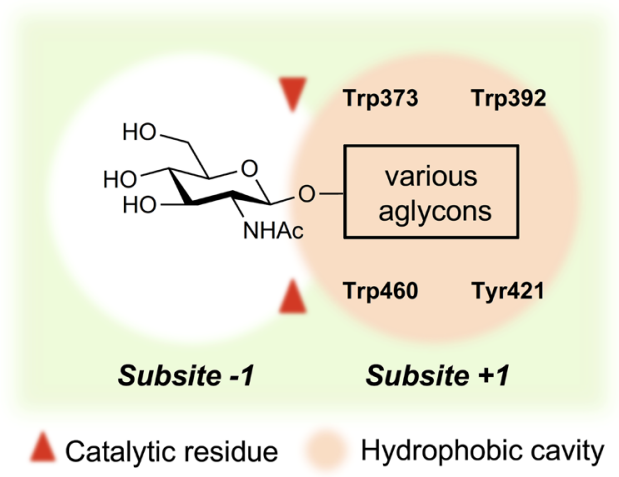

(B) hOGA active site

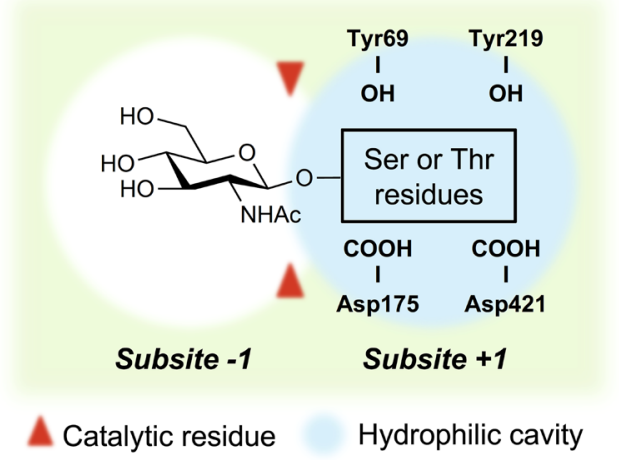

Fig. 1. Schematic Diagrams of the Active Site Structures, Human $\beta$ - $N$-Acetyl-D-hexosaminidase A (hHEXA) (A) and Human Protein $O$-GlcNAcase (hOGA) (B)

(Color figure can be accessed in the online version.)

and hOGA for constructing a cell-based direct high-throughput screening (HTS) system for their inhibitors. As the first target inhibitor enzyme, we selected hHEXA expressed in lysosomes from adherent human cultured cells, and hOGA, which is located in both the nucleus and cytoplasm, was chosen as the next target.

Previous inhibitor studies using in vitro assays used the commercially available hHEXA substrates, 4-nitrophenyl GlcNAc as a colorimetric substrate, ${ }^{9,10)}$ and 4-methylumbelliferyl GlcNAc, ${ }^{6,11)}$ fluorescein di-GlcNAc, ${ }^{12)}$ and HMRef $\mathrm{GlcNAc}^{13)}$ as fluorogenic substrates. However, although enzyme inhibitor screening and enzyme activitybased cell imaging of adherent cultured cells generally require a fluorogenic substrate, the use of 4-methylumbelliferone and fluorescein as a fluorophore will be ineffective at a low $\mathrm{pH}$, given the location of hHEXA, an acidic organelle ( $\mathrm{pH}$ approx. 3.5). ${ }^{14)}$ Therefore, we chose resorufin (excitation (EX) and emission (EM): 571 and $585 \mathrm{~nm}$, respectively), 2-methyl TokyoGreen (2MeTG; EX and EM: 491 and 510nm, respectively), and 4-trifluoromethylumbelliferone (TFMU; EX and EM: 385 and $502 \mathrm{~nm}$, respectively) as red, green, and blue fluorophores based on their distinct EX and EM wavelengths, excellent fluorescence quantum yields, and low $\mathrm{pH}$-dependent changes in fluorescence. ${ }^{15-18)}$ In this study, we present the design, synthesis, and cellular evaluation of novel three-color fluorogenic substrates for lysosome-localized hHEXA in three human cell lines. We believe that the designed substrates will contribute to the construction of a cell-based HTS system that could identify hHEXA inhibitors for PC therapy.

\section{Results and Discussion}

Design of Novel Quinone Methide Cleavage (QMC) Platform-Based hHEXA-Specific Fluorogenic Substrates The inhibitor development using the difference in the active site structure between hHEXA and hOGA was performed. GlcNAcstatin G, a highly selective, potent hOGA inhibitor, has been reported to possess $>900000$-fold selectivity over hHEXA/B ${ }^{8)}$ In this report, structural comparison of the active site pocket of mutant OGA that perfectly mimics the hOGA active site with that of hHEXA revealed apparent differences in the size and length of the binding pocket, with hHEXA having a narrower and shallower pocket than OGA. To logically design hHEXA-specific fluorogenic substrates based on this difference, we re-analyzed the active site structures of hHEXA (PDB ID: 2GJX) and hOGA (PDB ID: 5M7T), while also focusing on hydrophilic and hydrophobic interactions as an additional viewpoint. As a result, the active sites of both enzymes recognized the GlcNAc residue of the non-reducing end of the substrate at subsite -1 . Further, for hOGA, given that the hydrophilic nature of the L-serine and L-threonine residues of natural substrates were recognized at subsite +1 , it is also reasonable that the hydrophilic cavity formed with the phenols of Tyr69 and Tyr219 and the carboxy groups of Asp175 and Asp285 were located at subsite +1 . By contrast, a portion corresponding to the subsite +1 of hHEXA was a hydrophobic region composed of a variety of aromatic amino acid residues. The active sites of both enzymes are shown schematically in Fig. 1. Based on the analysis, hHEXAspecific substrates should have a structure wherein the hydrophobic functional group corresponding to the hydrophobic region at subsite +1 is inserted between the GlcNAc residue and the fluorophore of the known substrate. However, the insertion of such a functional group eliminates the release of the fluorophore following glycoside bond hydrolysis by hHEXA, thereby requiring a different approach to design fluorogenic substrates for hHEXA.

In our previous studies, we developed a QMC substratedesign platform to investigate the activities of Golgilocalized $\beta$-galactosidase, ${ }^{16)}$ Golgi-localized $\beta$-allosidase, ${ }^{17)}$ and lysosome-localized $\alpha$-L-fucosidase ${ }^{18)}$ as exo-acting glycan hydrolases. In the present study, we utilized the QMC platform to design hHEXA-specific fluorogenic substrates with benzyl group inserted as a hydrophobic group between the GlcNAc residue and the fluorophore of the known substrate (Fig. 2). This approach allows hHEXA-catalyzed hydrolysis to release fluorophore from the QMC reaction via a 1,6-elimination reaction that cleaves GlcNAc, thereby initiating a signal in the lysosome to report the location of hHEXA. The designed substrates will exhibit excellent specificity for hHEXA and improved fluorescence intensity at low $\mathrm{pH}$, and will have a low affinity for hOGA based on the hydrophobicity of the benzyl moiety. To efficiently observe hHEXA activity in cells, these substrates need to efficiently penetrate the cells and lysosomal membranes. Waring reported that to achieve a good membrane permeation, a $\log D$ value $>4.5$ is required for compounds with a molecular weight $(\mathrm{MW})>500 .{ }^{19)}$ Therefore, 


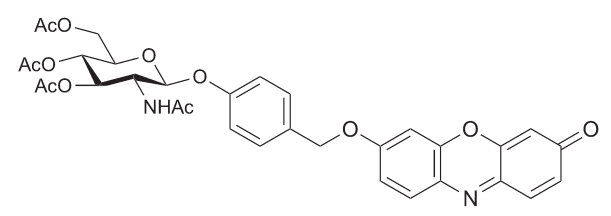

Substrate 1: Red, Ex/Em $=571 / 584 \mathrm{~nm}$

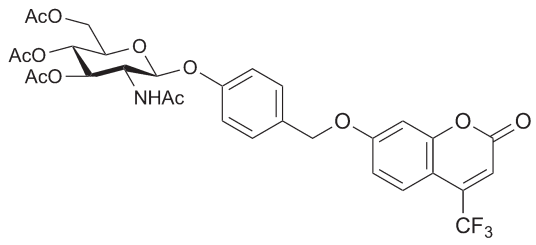

Substrate 2: Blue, Ex/Em = 385/502 nm

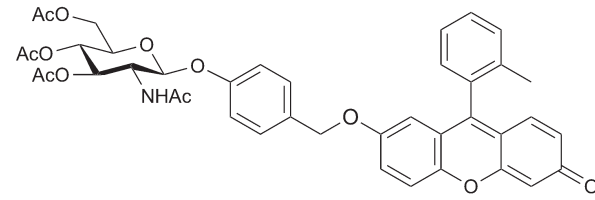

Substrate 3: Green, Ex/Em $=491 / 510 \mathrm{~nm}$

Fig. 2. Structure of Fluorogenic Substrate for hHEXA
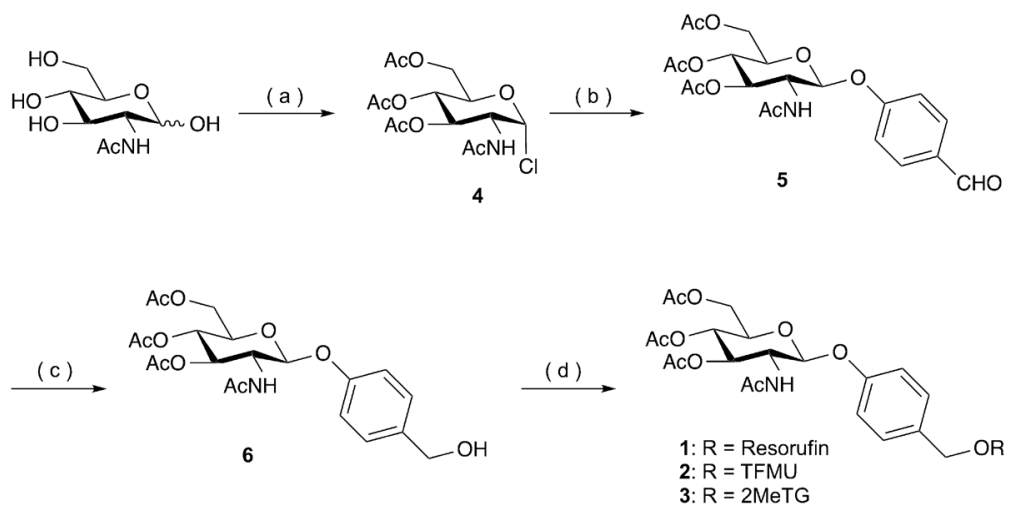

(a) Acetyl chloride, $69 \%$, (b) 4-Hydroxybenzaldehyde, Tetrabutylammonium hydrogen sulfate, $\mathrm{CH}_{2} \mathrm{Cl}_{2} / 1 \mathrm{M}$ $\mathrm{NaOH}(1 / 1), 87 \%$, (c) $\mathrm{NaBH}_{4}$, Methanol, 79\%, (d) Resorufin, 1,1'-(Azodicarbonyl)dipiperidine (ADDP), Tributylphosphine (TBP), THF, 1: 63\%, (d) TFMU, ADDP, TBP, THF, 2: 83\%, (d) 2MeTG, ADDP, TBP, THF, 3 $93 \%$.

Fig. 3. Synthesis Chart for Substrates $\mathbf{1}-\mathbf{3}$

we calculated the $c \log D$ values at physiological conditions, $\mathrm{pH}$ 3.0-8.5, and determined whether the substrates require hydroxyl or $O$-acetyl groups to achieve adequate membrane permeability. The $c \log D$ values of compounds that were deprotected of $O$-acetyl groups of substrates 1-3, which have MW $>500$, were $1.63,0.79$, and 4.29 , respectively, indicating that they do not have a sufficient membrane permeability. Conversely, the $c \log D$ values of acetylated substrates $\mathbf{1}-\mathbf{3}$, which have $\mathrm{MW}>500$, were significantly improved, being $3.40,2.56$, and 6.07 , respectively. This indicates that the acetylated substrates have a good membrane permeability. Furthermore, we previously reported that acetyl modification of the hydroxyl groups of a substrate effectively improves membrane permeability, without influencing the detection of glycosidase activity in living cells as these acetyl groups are removed by a cytosolic esterase. ${ }^{16-18)}$ However, these designed substrates, unlike the other QMC platform-based substrates that we developed, ${ }^{16-18)}$ possess an $\mathrm{N}$-acetyl group at the C2-position that can make neighboring groups participate in the hydrolysis of glycoside bonds. Since hHEXA is located in the lysosome as an acidic organelle, the stability of these substrates under the influence of the $\mathrm{N}$-acetyl group is an important viewpoint.
Previous studies have shown that an hHEX substrate with a similar structure is highly stable at $\mathrm{pH}$ ranges of 4.0-7.4, thus predicting that these designed substrates are also stable under the same conditions. ${ }^{20)}$

Synthesis of the Designed hHEXA-Specific Fluorogenic Substrates Substrates 1-3 were synthesized according to Fig. 3 via the shortest possible route. $N$-Acetylglucosamine, as the starting material, was acetylated and chlorinated to obtain 2-acetamido-3,4,6-tri- $O$-acetyl-2-deoxy- $\alpha$-D-glucopyranosyl chloride (4). ${ }^{21)}$ Compound 4 was glycosylated with 4-hydroxybenzaldehyde by $\beta$-specific glycosylation under phase transfer conditions to obtain 4-formylphenyl 2 -acetamido-3,4,6-tri- $O$-acetyl-2-deoxy- $\beta$-D-glucopyranoside $(5){ }^{22)}$ The formyl group of $\mathbf{5}$ was subsequently reduced to obtain 4-hydroxymethylphenyl 2-acetamido-3,4,6-tri$O$-acetyl-2-deoxy- $\beta$-D-glucopyranoside (6). ${ }^{22)}$ Compound 6 and a fluorophore (resorufin, TFMU, or $2 \mathrm{MeTG}^{23)}$ ) were reacted under Mitsunobu reaction conditions ${ }^{16-18)}$ to obtain fluorogenic substrates 1-3. In brief, these substrates were synthesized in four steps with excellent yields: 1, 30\%; 2, 39\%; and 3, 44\%. For a fluorogenic substrate to be effective, it must show a minimal fluorescence emission before hydrolysis. We confirmed 


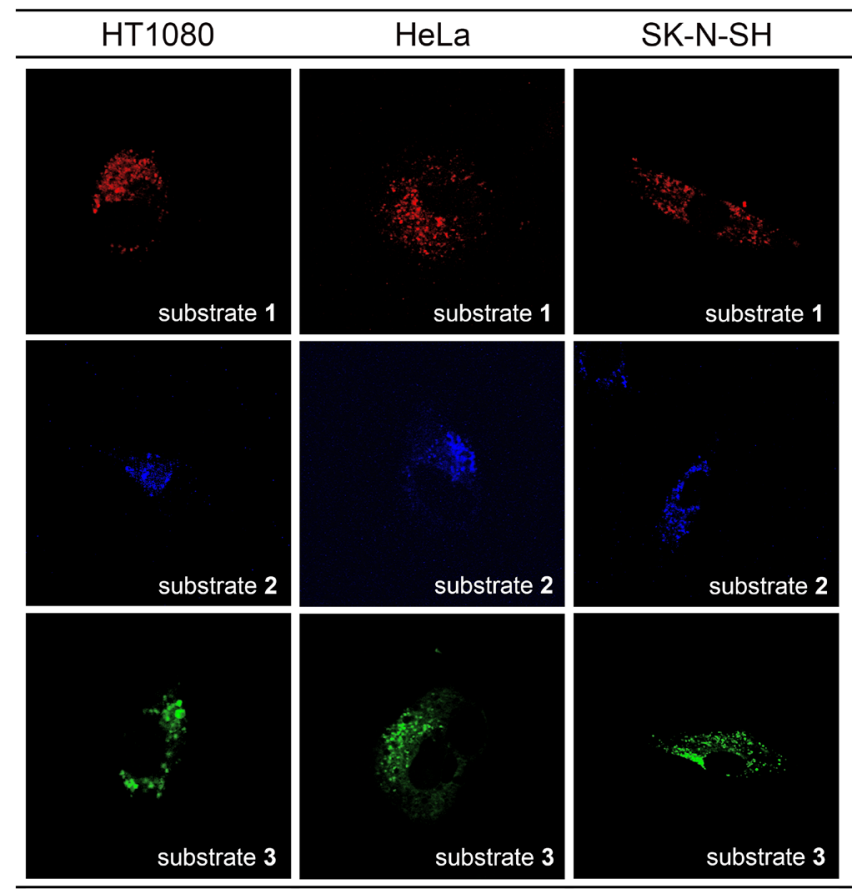

Fig. 4. Fluorescence Images of Fluorogenic Substrates 1-3 Based on Human $\beta$ - $N$-Acetyl-D-hexosaminidase A (hHEXA) Activity in Three Human Cell Lines

(Color figure can be accessed in the online version.)

this characteristic in substrates $\mathbf{1}-\mathbf{3}$ in phosphate-buffered saline (PBS), ensuring their status in a quenched state before hydrolysis (Figs. S1-S3 in the Supplementary Materials). With this, the stability of a substrate $\mathbf{1}$, as a representative molecule at $\mathrm{pH} 3.5$ for $48 \mathrm{~h}$ at $37^{\circ} \mathrm{C}$, was investigated. As a result, substrate 1 was very slightly hydrolyzed, but its stability in the assay conditions was ensured (Fig. S4 in the Supplementary Materials).

Cell-Based Evaluation of Fluorogenic Substrates for hHEXA To detect hHEXA activity in lysosomes in the adherent cultured cells, synthesized fluorogenic substrates 1-3 were evaluated in a human fibrosarcoma cell line (HT1080), a human cervical cancer cell line (HeLa), and a human neuroblastoma cell line (SK-N-SH) at final concentrations of $10 \mu \mathrm{M}$ for $2 \mathrm{~h}$, respectively (Fig. 4). The reported fluorescence signals from these substrates were recorded using a confocal laser scanning microscope. The observed bright fluorescence signals from substrates 1-3 revealed intercellular accumulation of each fluorophore at the nuclear periphery accompanied by a small-dot pattern typical of lysosome staining and not indicative of the endoplasmic reticulum and Golgi apparatus. The fluorescence intensities of $\mathbf{1}-\mathbf{3}$ in each cell line were independent of fluorophore structure. Based on our previous reports, no spontaneous cleavage of the glycosidic bond of a series of QMC platform-based substrates must take place by acidcatalyzed reaction at the $\mathrm{pH}$ of lysosomes. ${ }^{18)}$ More importantly, no unwanted fluorescence signals from hOGA activity were observed in the nucleus and cytoplasm where hOGA is located.

To identify the sublocalization of the observed hHEXA activity, we analyzed the observed staining area and organellespecific staining pattern of hHEXA activity using a commercially available lysosome-specific dye, Lyso-ID Green (green; EX and EM: 473 and $543 \mathrm{~nm}$ ). Lyso-ID Green was used to

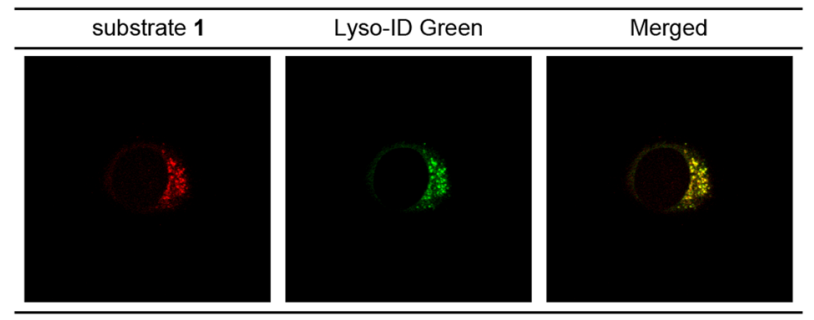

Fig. 5. Fluorescence and Merged Fluorescence Images of Substrate 1 (Red) and Lyso-ID Green (Green)

(Color figure can be accessed in the online version.)

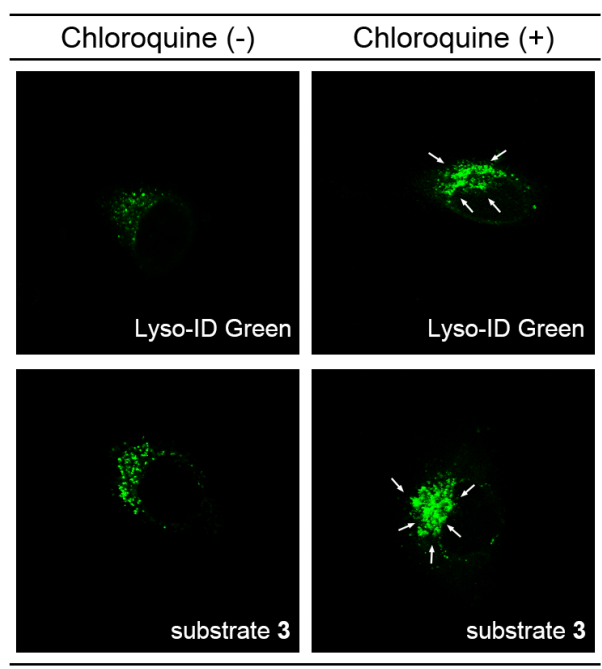

Fig. 6. Dynamic Change in Fluorescence Images of ChloroquineTreated HeLa Cells Stained with Human $\beta$ - $N$-Acetyl-D-hexosaminidase A (hHEXA) Substrate 3 and Lyso-ID Green

Arrows represent the enlarged lysosome following chloroquine treatment. (Color figure can be accessed in the online version.)

co-stain HeLa cells with fluorogenic substrate 1. Substrate $\mathbf{1}$ contains resorufin (red; EX and EM: 571 and $585 \mathrm{~nm}$ ) as the fluorophore, which offered a fluorescence window that is distinct from those provided by Lyso-ID Green. ${ }^{18)}$ Fluorescence signaling in the cells co-stained with substrate $\mathbf{1}$ and Lyso-ID Green was evident in the HeLa cell line, as shown in Fig. 5. The fluorescence signal obtained using substrate $\mathbf{1}$ agreed with the fluorescence signal from Lyso-ID Green at the nuclear peripheries. The conclusion from this correspondence is that the stained area of substrate $\mathbf{1}$ is the lysosome where hHEXA is located. Besides, subcellular localization of hHEXA activity in HeLa cells was assessed under inhibition of the lysosomal function by chloroquine. Previous reports have shown the ability of chloroquine to disrupt the lysosomal membrane by its detergent-like property, which results in the polymerization of the lysosomal membrane and enlargement of the lysosome. ${ }^{18,24)}$ Therefore, it was confirmed that enlargement of lysosomes fluorescently stained with Lyso-ID Green and substrate 3 was induced in the chloroquine-treated HeLa cells (green; EX and EM: 491 and 510 nm). After staining HeLa cells with substrate 3 and Lyso-ID Green independently, we found that chloroquine treatment enlarged the fluorescencestained lysosomes (Fig. 6). These observations of fluorophore localization in lysosomes of human cells based on endogenous hHEXA enzyme activity suggest that the designed substrates 

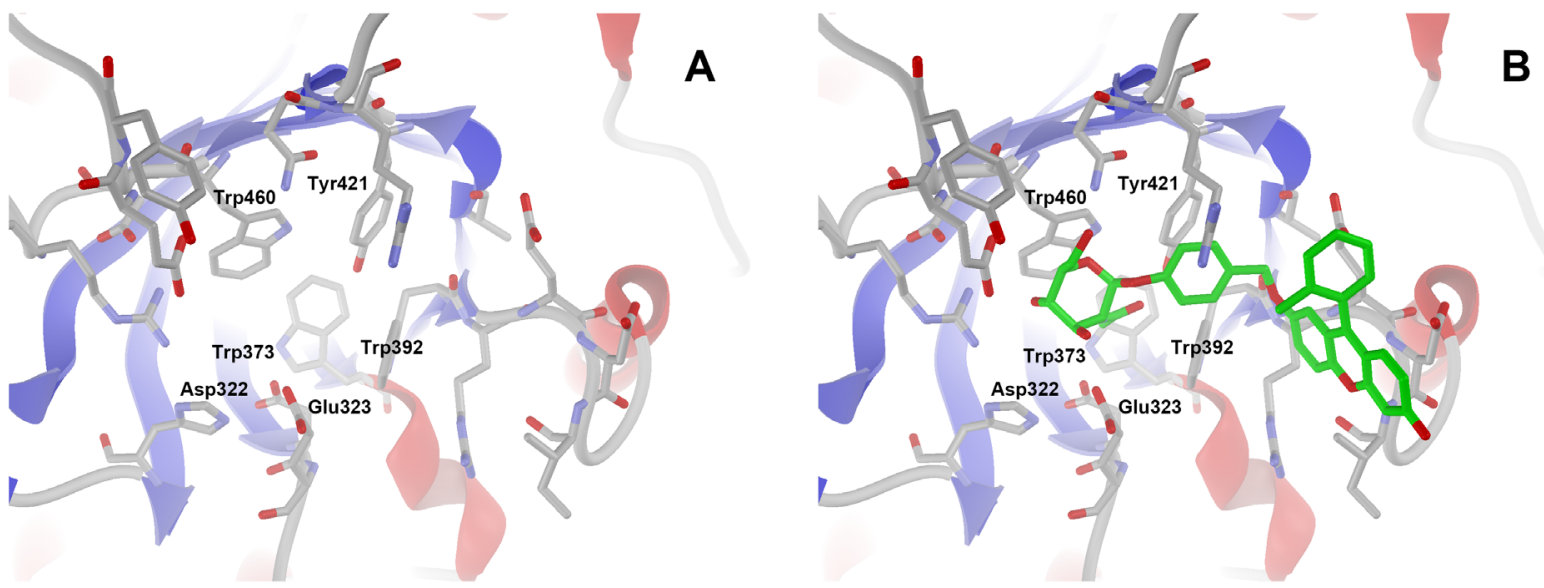

Fig. 7. (A) Close-Up Model of the Active Site of Human $\beta$-N-Acetyl-D-hexosaminidase A (hHEXA) from the Crystallographic Structure; (B) CloseUp Model of the Active Site of hHEXA vs. Deacetylated Substrate 3 from the Docking Model

Secondary structures on the active site are highlighted in red (helix) and blue (strand). (Color figure can be accessed in the online version.)

are hydrolyzed by hHEXA in lysosomes in living human cells.

Molecular Docking The molecular basis of the observed specificity of the substrates for hHEXA was investigated by molecular docking, which can effectively predict and characterize predominant binding modes of a ligand located in the active site. We performed molecular docking using the crystallographic structure of hHEXA (PDB ID: 2GJX), with deacetylated substrate $\mathbf{3}$ as a ligand. The active site closeup models of the crystallographic structure and the docking model are shown in Figs. 7A and 7B, respectively. The docking model revealed that the substrate-binding mode is similar to that of previously reported crystallographic structures of hHEXA vs. $\mathrm{N}$-acetylglucosamine-thiazoline as an inhibitor (PDB ID: 2GK1). In the crystallographic structure of hHEXA, Trp373 and Trp460 are located at subsite -1 , and Trp392 and Tyr421 form a hydrophobic region corresponding to subsite +1 of hOGA. A catalytic residue, Glu323, as a proton donor, is located at the center of subsite -1 and a hydrophobic region (Fig. 7A). In the docking model, the GlcNAc residue of the ligand was predicted to be recognized by $\operatorname{Trp} 373$ and Trp460, and the inserted benzyl moiety was also predicted to be recognized by the side chains of Trp392 and Tyr421 via a strong hydrophobicity, van der Waals interactions, and steric interactions (Fig. 7B). The docking model suggested the efficacy of the designed substrates to bind to the target active site appropriately, thereby suggesting their effectiveness as hHEXA-specific fluorogenic substrates and also explaining the observed specificity for hHEXA. The fluorogenic substrates we developed have the advantage of real-time detection and monitoring of SD- and TSD-related hHEXA activity in live cells, which are of paramount importance in the realm of disease diagnostics and drug screening.

\section{Conclusion}

In summary, we first designed three-color-specific fluorogenic substrates for hHEXA based on the recognition ability of subsite +1 of the active site by hydrophobic interaction, assessed their membrane permeability, and synthesized them efficiently via the shortest route. The designed and synthesized fluorogenic substrates were evaluated in three kinds of human cultured cells, revealing that they were not hydrolyzed by the analogous enzyme, hOGA, but were explicitly hydrolyzed by
hHEXA. Molecular modeling was used to analyze the specific recognition of the substrates, predicting that the hydrophobic interactions between aromatic amino acid residues and the benzyl moiety of the substrate located at subsite +1 play an important role. These designed substrates represent the firstin-a class of new substrates that can be utilized to screen hHEXA inhibitors in adherent human cultured cells. However, issues regarding the enzyme selectivity (hHEXA/hOGA) of our developed and known substrates for hHEXA would require further detailed experimentation and discussion using recombinant hHEXA and hOGA.

In the screening of hHEXA inhibitors from a compound library, the use of recombinant hHEXA is typical and desirable, but the preparation of hHEXA is not easy because hHEXA is heterodimeric. Given this fact, the utility and advantage of these substrates working at the cellular level should be high. Our future work will focus on constructing the HTS system of hHEXA inhibitors based on our previous study ${ }^{18)}$ and identifying hHEXA-specific inhibitors from a compound library to provide a basis for developing drugs for PC therapy of SD and TSD in the future.

\section{Experimental}

Chemistry New compounds were characterized by ${ }^{1} \mathrm{H}-\mathrm{NMR},{ }^{13} \mathrm{C}-\mathrm{NMR},{ }^{1} \mathrm{H}-{ }^{1} \mathrm{H}$ correlation spectroscopy, and heteronuclear multiple quantum coherence spectrometry, MS, and elemental analysis. The NMR spectra were recorded with a JEOL ECA500 spectrometer (JEOL, Tokyo, Japan; $500 \mathrm{MHz}$ for ${ }^{1} \mathrm{H}$ and $125 \mathrm{MHz}$ for ${ }^{13} \mathrm{C}$ ). Chemical shifts were expressed in $\mathrm{ppm}$ as downfield shifts from $\mathrm{Me}_{4} \mathrm{Si}$. Low-resolution mass spectra were obtained with an LCMS-2020 (Shimadzu, Kyoto, Japan) mass spectrometer, and the DUIS-2020 Dual Ion Source probe, which is coupled to a LC-2030C 3D (Shimadzu), was used for simultaneous electrospray ionization and atmospheric pressure chemical ionization measurement. Column chromatography was performed using Silica Gel 60N (Kanto Chemical, Tokyo, Japan, spherical neutral particle size: $100-210 \mu \mathrm{m})$. The progress of all reactions was monitored by TLC on Silica Gel $60 \mathrm{~F}_{254}, 0.25 \mathrm{~mm}$ (E. Merck, Darmstadt, Germany). Synthesis of 2-acetamido-3,4,6-tri$O$-acetyl-2-deoxy- $\alpha$-D-glucopyranosyl chloride (4), ${ }^{21)} 4$ formylphenyl 3,4,6-tri- $O$-acetyl-2-(acetamido)-2-deoxy- $\beta$-D- 
glucopyranoside (5), ${ }^{22)}$ and 4-(hydroxymethyl)phenyl 3,4,6-tri$O$-acetyl-2-(acetamido)-2-deoxy- $\beta$-D-glucopyranoside $(\mathbf{6})^{22)}$ was performed with a slight modification of the previously reported methods. NMR and DUIS-MS data of compounds 4-6 were consistent with the reported data.

Synthesis of Substrate 1 Compound $6(0.26 \mathrm{~g}, 0.56 \mathrm{mmol})$ dissolved in $15 \mathrm{~mL}$ of dry tetrahydrofuran (THF) was added to $1,1^{\prime}$-(azodicarbonyl)dipiperidine (ADDP, Tokyo Chemical Industry, Tokyo, Japan, A1051, $0.85 \mathrm{~g}, 3.38 \mathrm{mmol}$ ), tributylphosphine (TBP, Tokyo Chemical Industry, T0361, $0.85 \mathrm{~mL}$, $3.38 \mathrm{mmol}$ ), and resorufin (Sigma-Aldrich, St. Louis, MO, U.S.A., 424455, $0.14 \mathrm{~g}, 0.68 \mathrm{mmol}$ ). After stirring at room temperature (r.t., approximately $25^{\circ} \mathrm{C}$ ) for 60 min under $\mathrm{N}_{2}$ atmosphere, the mixture was poured into AcOEt and washed with saturated $\mathrm{NaHCO}_{3}$ (aq) and saturated $\mathrm{NaCl}$ (aq), and then dried over $\mathrm{Na}_{2} \mathrm{SO}_{4}$. The obtained residue was purified twice by column chromatography on silica gel (AcOEt) and silica gel $\left(10: 1, \mathrm{CH}_{2} \mathrm{Cl}_{2}: \mathrm{MeOH}\right)$ to obtain $0.23 \mathrm{~g}(63 \%$ yield $)$ of substrate 1. ${ }^{1} \mathrm{H}-\mathrm{NMR}\left(\mathrm{CDCl}_{3}\right) \delta: 1.96\left(3 \mathrm{H}, \mathrm{s},-\mathrm{CH}_{3}\right.$ in NHAc), $2.05(3 \mathrm{H}, \mathrm{s},-\mathrm{OAc}), 2.07(3 \mathrm{H} \times 2, \mathrm{~s},-\mathrm{OAc}), 3.88(1 \mathrm{H}$, $\left.\mathrm{ddd}, J_{4-5}=10.3 \mathrm{~Hz}, J_{5-6 \mathrm{a}}=2.5 \mathrm{~Hz}, J_{5-6 \mathrm{~b}}=5.3 \mathrm{~Hz}, \mathrm{H}-5\right), 4.10$ $\left(1 \mathrm{H}, \mathrm{ddd}, J_{1-2}=8.5 \mathrm{~Hz}, J_{2-3}=10.5 \mathrm{~Hz}, J_{2-\mathrm{NH}}=8.5 \mathrm{~Hz}, \mathrm{H}-2\right)$, $4.16\left(1 \mathrm{H}, \mathrm{dd}, J_{5-6 \mathrm{a}}=2.5 \mathrm{~Hz}, J_{6 \mathrm{a}-6 \mathrm{~b}}=12.5 \mathrm{~Hz}, \mathrm{H}-6 \mathrm{a}\right), 4.29(1 \mathrm{H}$, $\left.\mathrm{dd}, J_{5-6 \mathrm{~b}}=5.0 \mathrm{~Hz}, J_{6 \mathrm{a}-6 \mathrm{~b}}=12.0 \mathrm{~Hz}, \mathrm{H}-6 \mathrm{~b}\right), 5.10(2 \mathrm{H}, \mathrm{s}$, benzyl position), $5.15\left(1 \mathrm{H}, \mathrm{dd}, J_{3-4}=J_{4-5}=9.8 \mathrm{~Hz}, \mathrm{H}-4\right), 5.33(1 \mathrm{H}, \mathrm{d}$, $\left.J_{1-2}=8.0 \mathrm{~Hz}, \mathrm{H}-1\right), 5.44\left(1 \mathrm{H}, \mathrm{dd}, J_{2-3}=10.5 \mathrm{~Hz}, J_{3-4}=9.5 \mathrm{~Hz}\right.$, $\mathrm{H}-3), 5.66\left(1 \mathrm{H}, \mathrm{d}, J_{2-\mathrm{NH}}=8.5 \mathrm{~Hz},-\mathrm{NHAc}\right), 6.31(1 \mathrm{H}, \mathrm{d}$, $J=2.5 \mathrm{~Hz}), 6.83(1 \mathrm{H}, \mathrm{dd}, J=2.3 \mathrm{~Hz}, J=10.3 \mathrm{~Hz}), 6.86(1 \mathrm{H}, \mathrm{d}$, $J=2.5 \mathrm{~Hz}), 6.98(1 \mathrm{H}, \mathrm{dd}, J=2.5 \mathrm{~Hz}, J=9.0 \mathrm{~Hz}), 7.03(2 \mathrm{H}, \mathrm{d}$, $J=9.0 \mathrm{~Hz}), 7.36(2 \mathrm{H}, \mathrm{d}, J=8.5 \mathrm{~Hz}), 7.42(1 \mathrm{H}, \mathrm{d}, J=10.0 \mathrm{~Hz})$, $7.70(1 \mathrm{H}, \mathrm{d}, J=8.5 \mathrm{~Hz}) ;{ }^{13} \mathrm{C}-\mathrm{NMR}\left(\mathrm{CDCl}_{3}\right) \delta: 20.74\left(-\mathrm{CH}_{3}\right)$, $20.81\left(-\mathrm{CH}_{3}\right), 23.46\left(2 \times-\mathrm{CH}_{3}\right), 54.99(\mathrm{C} 2), 62.16$ (C6), 68.49 (C4), 70.47 (benzyl position), 71.90 (C3), 72.12 (C5), 98.77 (C1), 101.09, 106.84, 114.31, 117.23, 128.56, 129.26, 130.09, $131.70,134.35,134.79,145.66,145.78,149.86,157.19,162.61$, $169.50(-\mathrm{C}=\mathrm{O}, \mathrm{Ac}), 170.44(-\mathrm{C}=\mathrm{O}, \mathrm{Ac}), 170.67(-\mathrm{C}=\mathrm{O}, \mathrm{Ac})$, $170.92(-\mathrm{C}=\mathrm{O}, \mathrm{Ac}), 186.40 \quad(-\mathrm{C}=\mathrm{O}$, resorufin $)$; DUIS-MS (positive mode): $m / z=649[\mathrm{M}+\mathrm{H}]^{+}$and $671[\mathrm{M}+\mathrm{Na}]^{+}$, (negative mode): $m / z=647[\mathrm{M}-\mathrm{H}]^{-}$; Anal. Calcd for $\mathrm{C}_{33} \mathrm{H}_{32} \mathrm{~N}_{2} \mathrm{O}_{12}$ : C, 61.11; H, 4.97; N, 4.32. Found: C, 61.12; H, 4.96; N, 4.15.

Synthesis of Substrate 2 Compound $6(0.24 \mathrm{~g}, 0.52 \mathrm{mmol})$ dissolved in $15 \mathrm{~mL}$ of dry THF was added to ADDP $(0.79 \mathrm{~g}$, $3.13 \mathrm{mmol})$, TBP $(0.80 \mathrm{~mL}, 3.13 \mathrm{mmol})$, and TFMU (Santa Cruz Biotechnology, Dallas, TX, U.S.A.; sc-210622 A, 0.14 g, $0.63 \mathrm{mmol}$ ). After stirring at r.t. for $60 \mathrm{~min}$ under $\mathrm{N}_{2}$ atmosphere, the mixture was poured into AcOEt and washed with saturated $\mathrm{NaHCO}_{3}$ (aq) and saturated $\mathrm{NaCl}$ (aq), and then dried over $\mathrm{Na}_{2} \mathrm{SO}_{4}$. The obtained residue was purified once by column chromatography on silica gel (AcOEt) and twice by column chromatography on silica gel $\left(10: 1, \mathrm{CH}_{2} \mathrm{Cl}_{2}: \mathrm{MeOH}\right)$ to obtain $0.29 \mathrm{~g} \quad(83 \%$ yield $)$ of substrate $2 .{ }^{1} \mathrm{H}-\mathrm{NMR}$ $\left(\mathrm{CDCl}_{3}: \mathrm{CD}_{3} \mathrm{OD}, 4: 1\right) \delta: 1.94\left(3 \mathrm{H}, \mathrm{s},-\mathrm{CH}_{3}\right.$ in $\left.\mathrm{NHAc}\right), 2.07(3 \mathrm{H}$ $\times 2, \mathrm{~s},-\mathrm{OAc}), 2.10(3 \mathrm{H}, \mathrm{s},-\mathrm{OAc}), 3.93\left(1 \mathrm{H}, \mathrm{ddd}, J_{4-5}=9.5 \mathrm{~Hz}\right.$, $\left.J_{5-6 \mathrm{a}}=2.5 \mathrm{~Hz}, J_{5-6 \mathrm{~b}}=5.0 \mathrm{~Hz}, \mathrm{H}-5\right), 4.14-4.18(2 \mathrm{H}, \mathrm{m}, \mathrm{H}-2$ and H-6a), $4.31\left(1 \mathrm{H}, \mathrm{dd}, J_{5-6 \mathrm{~b}}=5.5 \mathrm{~Hz}, J_{6 \mathrm{a}-6 \mathrm{~b}}=12.5 \mathrm{~Hz}, \mathrm{H}-6 \mathrm{~b}\right)$, $5.13(2 \mathrm{H}, \mathrm{s}$, benzyl position), $5.13(1 \mathrm{H}, \mathrm{m}, \mathrm{H}-4), 5.31(1 \mathrm{H}, \mathrm{d}$, $\left.J_{1-2}=8.5 \mathrm{~Hz}, \mathrm{H}-1\right), 5.37\left(1 \mathrm{H}, \mathrm{dd}, J_{2-3}=J_{3-4}=10.0 \mathrm{~Hz}, \mathrm{H}-3\right)$, $6.65(1 \mathrm{H}, \mathrm{s}), 6.97(1 \mathrm{H}, \mathrm{d}, J=2.0 \mathrm{~Hz}), 7.02(1 \mathrm{H}, \mathrm{dd}, J=2.3 \mathrm{~Hz}$, $J=9.3 \mathrm{~Hz}), 7.05(2 \mathrm{H}, \mathrm{d}, J=8.5 \mathrm{~Hz}), 7.38(2 \mathrm{H}, \mathrm{d}, J=8.5 \mathrm{~Hz})$, $7.66(1 \mathrm{H}, \mathrm{d}, J=8.0 \mathrm{~Hz}) ;{ }^{13} \mathrm{C}-\mathrm{NMR}\left(\mathrm{CDCl}_{3}: \mathrm{CD}_{3} \mathrm{OD}, 4: 1\right) \delta$ : $20.68\left(-\mathrm{CH}_{3}\right), 20.78\left(-\mathrm{CH}_{3}\right), 22.75\left(-\mathrm{CH}_{3}\right), 30.98\left(-\mathrm{CH}_{3}\right), 54.42$
(C2), 62.38 (C6), 68.89 (C4), 70.42 (benzyl position), 71.93 (C3), 72.54 (C5), 98.78 (C1), 102.58, 107.411, 112.33, 114.37, 117.24, $121.74\left(\mathrm{~d}, J=274.3 \mathrm{~Hz},-\mathrm{CF}_{3}\right), 126.62,129.41,130.17$, 142.06 (q, $\left.J_{\mathrm{C}-\mathrm{F}}=33.0 \mathrm{~Hz},-\mathrm{C}-\mathrm{CF}_{3}\right), 156.36,157.36,160.17$, $162.82(-\mathrm{C}=\mathrm{O}, \mathrm{TFMU}), 170 . \overline{1} 1 \quad(-\mathrm{C}=\mathrm{O}, \mathrm{Ac}), 171.24(-\mathrm{C}=\mathrm{O}$, Ac), $171.37(-\mathrm{C}=\mathrm{O}, \mathrm{Ac}), 172.07(-\mathrm{C}=\mathrm{O}, \mathrm{Ac})$; DUIS-MS (positive mode): $m / z=666[\mathrm{M}+\mathrm{H}]^{+}$and $688[\mathrm{M}+\mathrm{Na}]^{+}$, (negative mode): $m / z=664[\mathrm{M}-\mathrm{H}]^{-}$; Anal. Calcd for $\mathrm{C}_{31} \mathrm{H}_{30} \mathrm{~F}_{3} \mathrm{NO}_{12}: \mathrm{C}$, 55.94; H, 4.54; N, 2.10. Found: C, 56.05; H, 4.73; N, 2.06.

Synthesis of Substrate 3 Compound $6(0.27 \mathrm{~g}, 0.61 \mathrm{mmol})$ dissolved in $15 \mathrm{~mL}$ of dry THF was added to ADDP $(0.92 \mathrm{~g}$, $3.64 \mathrm{mmol})$, TBP $(0.90 \mathrm{~mL}, 3.64 \mathrm{mmol})$, and $2 \mathrm{MeTG}(0.22 \mathrm{~g}$, $0.73 \mathrm{mmol}$ ). After stirring at r.t. for $60 \mathrm{~min}$ under $\mathrm{N}_{2}$ atmosphere, the mixture was poured into AcOEt and washed with saturated $\mathrm{NaHCO}_{3}$ (aq) and saturated $\mathrm{NaCl}$ (aq), and then dried over $\mathrm{Na}_{2} \mathrm{SO}_{4}$. The obtained residue was purified five times by column chromatography on silica gel $(10: 1$, $\left.\mathrm{CH}_{2} \mathrm{Cl}_{2}: \mathrm{MeOH}\right)$ to obtain $0.42 \mathrm{~g}$ (93\% yield) of substrate 3 . ${ }^{1} \mathrm{H}-\mathrm{NMR}\left(\mathrm{CDCl}_{3}\right) \delta$ : $1.97\left(3 \mathrm{H}, \mathrm{s},-\mathrm{CH}_{3}\right.$ in NHAc), 2.06 and $2.08\left(3 \mathrm{H} \times 4, \mathrm{~s} \times 2,-\mathrm{OAc}\right.$ and $-\mathrm{CH}_{3}$ in $\left.2 \mathrm{MeTG}\right), 3.89(1 \mathrm{H}$, ddd, $\left.J_{4-5}=9.5 \mathrm{~Hz}, J_{5-6 \mathrm{a}}=2.6 \mathrm{~Hz}, J_{5-6 \mathrm{~b}}=5.4 \mathrm{~Hz}, \mathrm{H}-5\right), 4.11$ $\left(1 \mathrm{H}, \mathrm{ddd}, J_{1-2}=8.5 \mathrm{~Hz}, J_{2-3}=10.5 \mathrm{~Hz}, J_{2-\mathrm{NH}}=8.5 \mathrm{~Hz}, \mathrm{H}-2\right)$, $4.17\left(1 \mathrm{H}, \mathrm{dd}, J_{5-6 \mathrm{a}}=2.3 \mathrm{~Hz}, J_{6 \mathrm{a}-6 \mathrm{~b}}=12.3 \mathrm{~Hz}, \mathrm{H}-6 \mathrm{a}\right), 4.30(1 \mathrm{H}$, $\left.\mathrm{dd}, J_{5-6 \mathrm{~b}}=5.3 \mathrm{~Hz}, J_{6 \mathrm{a}-6 \mathrm{~b}}=12.3 \mathrm{~Hz}, \mathrm{H}-6 \mathrm{~b}\right), 5.12(2 \mathrm{H}, \mathrm{s}$, benzyl position), $5.16\left(1 \mathrm{H}, \mathrm{dd}, J_{3-4}=J_{4-5}=9.8 \mathrm{~Hz}, \mathrm{H}-4\right), 5.35(1 \mathrm{H}, \mathrm{d}$, $\left.J_{1-2}=8.0 \mathrm{~Hz}, \mathrm{H}-1\right), 5.45\left(1 \mathrm{H}, \mathrm{dd}, J_{2-3}=J_{3-4}=10.0 \mathrm{~Hz}, \mathrm{H}-3\right)$, $5.80\left(1 \mathrm{H}, \mathrm{d}, J_{2-\mathrm{NH}}=8.5 \mathrm{~Hz},-\mathrm{NHAc}\right), 6.45(1 \mathrm{H}, \mathrm{d}, J=2.5 \mathrm{~Hz})$, $6.58(1 \mathrm{H}, \mathrm{dd}, J=2.0 \mathrm{~Hz}, J=9.5 \mathrm{~Hz}), 6.81(1 \mathrm{H}, \mathrm{dd}, J=2.5 \mathrm{~Hz}$, $J=9.0 \mathrm{~Hz}), 6.95(1 \mathrm{H}, \mathrm{d}, J=9.5 \mathrm{~Hz}), 6.98(1 \mathrm{H}, \mathrm{d}, J=9.0 \mathrm{~Hz})$, $7.01(1 \mathrm{H}, \mathrm{d}, J=2.0 \mathrm{~Hz}), 7.04(2 \mathrm{H}, \mathrm{d}, J=8.5 \mathrm{~Hz}), 7.16(1 \mathrm{H}, \mathrm{d}$, $J=7.0 \mathrm{~Hz}), 7.36-7.41(2 \mathrm{H}, \mathrm{m}), 7.37(2 \mathrm{H}, \mathrm{d}, J=8.5 \mathrm{~Hz}), 7.46$ $(1 \mathrm{H}, \mathrm{ddd}, J=1.5 \mathrm{~Hz}, J=7.5 \mathrm{~Hz}) ;{ }^{13} \mathrm{C}-\mathrm{NMR}\left(\mathrm{CDCl}_{3}\right): \delta 19.65$ $\left(-\mathrm{CH}_{3}\right), 20.66\left(-\mathrm{CH}_{3}\right), 20.73\left(2 \times-\mathrm{CH}_{3}\right), 22.38\left(-\mathrm{CH}_{3}\right), 54.90$ (C2), 62.10 (C6), 68.45 (C4), 70.27 (benzyl position), 71.87 (C3), 72.03 (C5), 98.69 (C1), 101.31, 105.81, 114.01, 114.54, $117.17,118.35,126.14,129.07,129.18,129.48,129.53,130.06$, $130.16,130.60(\times 2), 132.46,136.17,149.40,154.54,157.13$, 158.92, 163.24, $169.43(-\mathrm{C}=\mathrm{O}, \mathrm{Ac}), 170.41(-\mathrm{C}=\mathrm{O}, \mathrm{Ac}), 170.59$ $(-\mathrm{C}=\mathrm{O}, \mathrm{Ac}), 170.82(-\mathrm{C}=\mathrm{O}, \mathrm{Ac}), 185.82(-\mathrm{C}=\mathrm{O}, 2 \mathrm{MeTG})$; DUIS-MS (positive mode): $m / z=738[\mathrm{M}+\mathrm{H}]^{+}$and 760 $[\mathrm{M}+\mathrm{Na}]^{+}$, (negative mode): $m / z=736[\mathrm{M}-\mathrm{H}]^{-} ;$Anal. Calcd for $\mathrm{C}_{41} \mathrm{H}_{39} \mathrm{NO}_{12}: \mathrm{C}, 66.75 ; \mathrm{H}, 5.33 ; \mathrm{N}, 1.90$. Found: $\mathrm{C}, 66.75 ; \mathrm{H}$, 5.30; N, 1.82 .

Photochemical Characterization of Substrates 1-3 and Stability of Substrate 1 The assay for the photochemical characterization of substrates $\mathbf{1}-\mathbf{3}$ was as follows. Solutions of resorufin and substrate $\mathbf{1}$ were prepared at $10 \mathrm{nM}$ in PBS containing $2.0 \times 10^{-4} \%$ dimethyl sulfoxide (DMSO). Solutions of TFMU and substrate 2 were prepared at $100 \mathrm{nM}$ in PBS containing $1.0 \times 10^{-3} \%$ DMSO. Solutions of $2 \mathrm{MeTG}$ and substrate 3 were prepared at $10 \mathrm{nM}$ in PBS containing $1.0 \times 10^{-4} \%$ DMSO. The fluorescence emission spectra of these solutions were recorded at the following EX wavelengths: resorufin and substrate 1: $571 \mathrm{~nm}$; TFMU and substrate 2: $385 \mathrm{~nm}$; and 2MeTG and substrate 3: $491 \mathrm{~nm}$. The stability assay for substrate 1 was performed as follows. The solution of substrate 1 was prepared at $10 \mathrm{nM}$ in $50 \mathrm{mM}$ sodium citrate buffer $(\mathrm{pH}$ 3.5) containing $2.0 \times 10^{-4} \% \mathrm{DMSO}$. The solution was kept at $37^{\circ} \mathrm{C}$, and the fluorescence emission spectrum of the solution was recorded based on the EX wavelength at $571 \mathrm{~nm}$ after 0 , 24 , and $48 \mathrm{~h}$. The fluorescence spectrum of each solution was 
recorded using a RF-5300PC spectrofluorophotometer (Shimadzu). The results are shown in Figs. S1-S4 in the Supplementary Materials.

Calculation of Distribution Coefficient $(c \log D)$ Values for Substrates 1-3 The $c \log D$ values for substrates 1-3 were calculated using Structure Design Suite version 12.01 from Advanced Chemistry Development Inc. (Toronto, Canada).

Docking Study of hHEXA versus Deacetylated Substrate 3 Molecular docking simulations of the $\alpha$ subunit of hHEXA (PDB ID: 2GJX, chain A) to deacetylated substrate $\mathbf{3}$ were carried out using the Molegro Virtual Docker (version 7.0.0; Molexus, Odder, Denmark). Several preliminary steps were required before docking, such as removing water, ligands, and non-targeted protein chains, and adding hydrogens. In these experiments, we used MolDock score [GRID] function, which is based on a piecewise linear potential, and a re-ranking procedure was applied to the highest ranked poses to increase the docking accuracy. Affinity grid resolution was set to $0.3 \AA$. Ligand evaluations were based on internal energy of binding, internal H-bond formation, and $\mathrm{Sp} 2-\mathrm{Sp} 2$ (trigonal planar electron domain geometry) torsion angles. Candidate cavities for ligand docking were detected by inclusion of pockets with a volume of $10-10000 \AA^{3}$ and grid resolution of 0.6 . Among the candidate cavities, the cavity that included the catalytic residue Glu 323 was selected as an active site for docking. The cavity was measured for cavity volume $\left(70.2 \AA^{3}\right)$, surface $\left(319.68 \AA^{2}\right)$, and radius $(15.0 \AA)$. The search algorithm was set to MolDock Optimizer, which is customized with constraining poses to the cavity, for docking energy minimization and H-bond optimization. The number of runs was 15, and parameter settings were 10000 iterations, 50 population sizes, 0.50 scaling factor, and 0.90 crossover rate. All dockings were performed at $0.70 \AA$ root-mean-square deviation threshold.

Biology Low-glucose Dulbecco's modified Eagle's medium (D6046) was purchased from Sigma-Aldrich. CELLECT fetal bovine serum (S1820) was purchased from MP Biomedicals (Santa Ana, CA, U.S.A.). The Lyso-ID ${ }^{\mathrm{TM}}$ Green Assay Kit (ENZ-51028-K100) was purchased from ENZO Life Sciences (Lausen, Switzerland). Chloroquine diphosphate (038-17971) was purchased from FUJIFILM Wako Pure Chemical Corporation (Osaka, Japan). A 35-mm-high $\mu$-Dish for cell imaging (ib81156) was purchased from ibidi (Gräfelfing, Germany). The human fibrosarcoma cell line, HT-1080 (JCRB9113), was provided by the JCRB cell bank of the National Institutes of Biomedical Innovation, Health and Nutrition, Japan. The human cervical cancer cell line, HeLa (RCB0007), and the human neuroblastoma cell line, SK-N-SH (RCB0426), were provided by the RIKEN BRC through the National BioResource Project of the MEXT/AMED, Japan. Fluorescence intensities were recorded using a FluoView FV1000-D Confocal Laser Scanning Microscope (Olympus, Tokyo, Japan) equipped with filter sets for Alexa Fluor 488 (EX, $473 \mathrm{~nm}$; dichroic filter, 405/473; and EM, 490-590 nm) for 2MeTG measurements; FITC (EX, $473 \mathrm{~nm}$; dichroic filter, 405/473; and EM, 490-590 nm) for Lyso-ID ${ }^{\mathrm{TM}}$ Green measurements; Alexa Fluor 568 (EX, 559 nm; dichroic filter, 405/473/559; EM, 575-675 nm) for resorufin measurements; and DAPI (EX, $405 \mathrm{~nm}$; dichroic filter, 405/473; EM, 430-455 nm) for TFMU measurements. Reagent-treated cells were simply washed and immediately fixed with $10 \%$ formalin, and then the fluores- cence signal of the cells was recorded. Each experiment was performed at least three times.

Cell-Based Fluorescence Imaging Assay with Substrates 1-3 in Three Cell Lines HT-1080, HeLa, and SK-N-SH cells were seeded in $\mu$-Dishes at $4.0 \times 10^{4}$ cells/dish. After incubating the cells at $37^{\circ} \mathrm{C}$ in $5 \% \mathrm{CO}_{2}$ for $24 \mathrm{~h}$, the medium was replaced with $1 \mathrm{~mL}$ of fresh medium. Subsequently, $5 \mu \mathrm{L}$ of $2 \mathrm{mM}$ DMSO solutions of substrates 1-3 were added to each dish $(10 \mu \mathrm{M}$ final concentration), and then the cells were incubated at $37^{\circ} \mathrm{C}$ in $5 \% \mathrm{CO}_{2}$ for $2 \mathrm{~h}$.

Cell-Based Fluorescence Imaging Assay with Substrate 1 and Lyso-ID Green HeLa cells were seeded in $\mu$-Dishes at $4.0 \times 10^{4}$ cells/dish. After incubating the cells at $37^{\circ} \mathrm{C}$ in $5 \% \mathrm{CO}_{2}$ for $24 \mathrm{~h}$, the medium was replaced with $1 \mathrm{~mL}$ of fresh medium. Subsequently, $5 \mu \mathrm{L}$ of $2 \mathrm{mM}$ DMSO solution of substrate 1 was added to the dishes $(10 \mu \mathrm{M}$ final concentration), and the cells were incubated for $2 \mathrm{~h}$. Next, $200 \mu \mathrm{L}$ of Lyso-ID Green dye solution was added, and the cells were incubated for $30 \mathrm{~min}$, in the dark. The cells were washed three times with $200 \mu \mathrm{L}$ of assay buffer in Lyso-ID ${ }^{\mathrm{TM}}$ Green Assay Kit.

Cell-Based Fluorescence Imaging Assay with LysoID Green Using Chloroquine HeLa cells were seeded in $\mu$-Dishes at $4.0 \times 10^{4}$ cells $/$ dish. After incubating the cells for at $37^{\circ} \mathrm{C}$ in $5 \% \mathrm{CO}_{2}$ for $24 \mathrm{~h}$, the medium was replaced with $1 \mathrm{~mL}$ of fresh medium. Subsequently, $5 \mu \mathrm{L}$ of $15 \mathrm{mM}$ chloroquine diphosphate water solution ( $75 \mu \mathrm{M}$ final concentration) was added to the dish, and the cells were incubated at $37^{\circ} \mathrm{C}$ in $5 \% \mathrm{CO}_{2}$ for $2 \mathrm{~h}$. Next, $200 \mu \mathrm{L}$ of Lyso-ID Green dye solution was added, and the cells were incubated for $30 \mathrm{~min}$ in the dark. The cells were then washed three times with $200 \mu \mathrm{L}$ of assay buffer in Lyso-ID ${ }^{\mathrm{TM}}$ Green Assay Kit.

Cell-Based Fluorescence Imaging Assay with Substrate 3 Using Chloroquine HeLa cells were seeded in $\mu$-Dishes at $4.0 \times 10^{4}$ cells/dish. After incubating the cells at $37^{\circ} \mathrm{C}$ in $5 \% \mathrm{CO}_{2}$ for $24 \mathrm{~h}$, the medium was replaced with $1 \mathrm{~mL}$ of fresh medium. Subsequently, $5 \mu \mathrm{L}$ of $15 \mathrm{mM}$ chloroquine diphosphate water solution ( $75 \mu \mathrm{M}$ final concentration) was added to the dish, and the cells were incubated at $37^{\circ} \mathrm{C}$ in $5 \% \mathrm{CO}_{2}$ for $2 \mathrm{~h}$. Next, $5 \mu \mathrm{L}$ of $2 \mathrm{mM}$ DMSO solution of substrate $3(10 \mu \mathrm{M}$ final concentration) was added to the dish, and the cells were incubated for $1 \mathrm{~h}$.

Acknowledgments We thank A. Sato of A-Rabbit-Science Japan Co., Ltd., for performing the elemental analyses. This research was supported in part by a Grant from the College of Bioresource Sciences, Nihon University, Japan. The illustration of HeLa cells in Graphical Abstract was obtained from TogoTV (C2016 DBCLS TogoTV).

Conflict of Interest The authors declare no conflict of interest.

Supplementary Materials The online version of this article contains supplementary materials.

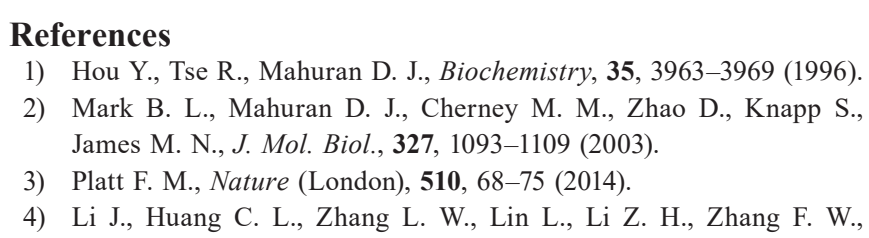


Wang P., Biochemistry (Mosc.), 75, 938-943 (2010).

5) Yang Y. R., Song M., Lee H., Jeon Y., Choi E. J., Jang H. J., Moon H. Y., Byun H. Y., Kim E. K., Kim D. H., Lee M. N., Koh A., Ghim J., Choi J. H., Lee-Kwon W., Kim K. T., Ryu S. H., Suh P. G., Aging Cell, 11, 439-448 (2012).

6) Tropak M. B., Blanchard J. E., Withers S. G., Brown E. D., Mahuran D., Chem. Biol., 14, 153-164 (2007).

7) Selnick H. G., Hess J. F., Tang C., et al., J. Med. Chem., 62, 10062 10097 (2019).

8) Dorfmueller H. C., Borodkin V. S., Schimpl M., Zheng X., Kime R., Read K. D., van Aalten D. M., Chem. Biol., 17, 1250-1255 (2010).

9) Dos Reis D. C., Damasceno K. A., de Campos C. B., Veloso E. S. Pêgas G. R. A., Kraemer L. R., Rodrigues M. A., Mattos M. S., Gomes D. A., Campos P. P., Ferreira E., Russo R. C., Cassali G. D., Front. Oncol, 9, 577 (2019).

10) Weber P., Nasseri S. A., Pabst B. M., Torvisco A., Müller P., Paschke E., Tschernutter M., Windischhofer W., Withers S. G., Wrodnigg T. M., Stütz A. E., Molecules, 23, E708 (2018).

11) Shen S., Chen W., Dong L., Yang Q., Lu H., Zhang J., J. Enzyme Inhib. Med. Chem., 33, 445-452 (2018).

12) Kim E. J., Kang D. O., Love D. C., Hanover J. A., Carbohydr. Res., 341, 971-982 (2006).
13) Matsuzaki H., Kamiya M., Iwatate R. J., Asanuma D., Watanabe T., Urano Y., Bioconjug. Chem., 27, 973-981 (2016).

14) Wu L., Wang Y., James T. D., Jia N., Huang C., Chem. Commun., 54, 5518-5521 (2018).

15) Hakamata W., Tamura S., Hirano T., Nishio T., ACS Med. Chem. Lett., 5, 321-325 (2014).

16) Hakamata W., Miura K., Hirano T., Nishio T., Bioorg. Med. Chem., 23, 73-79 (2015).

17) Miura K., Hakamata W., Tanaka A., Hirano T., Nishio T., Bioorg. Med. Chem., 24, 1369-1375 (2016).

18) Miura K., Tsukagoshi T., Hirano T., Nishio T., Hakamata W., ACS Med. Chem. Lett., 10, 1309-1313 (2019).

19) Waring M. J., Expert Opin. Drug Discov., 5, 235-248 (2010).

20) Wang Q., Li C., Chen Q., Zhang P., Wang D., Kang M., Jiang G., Wang J., Anal. Chem., 91, 12611-12614 (2019).

21) Horton D., "General Carbohydrate Method," First ed., Section II, ed. by Whistler R. L., BeMiller J. N., Academic Press, Massachusetts, 1972, pp. 282-285.

22) René R., François D. T., Can. J. Chem., 69, 817-821 (1991).

23) Urano Y., Kamiya M., Kanda K., Ueno T., Hirose K., Nagano T., $J$. Am. Chem. Soc., 127, 4888-4894 (2005).

24) Boya P., Kroemer G., Oncogene, 27, 6434-6451 (2008). 